УДК 378.016:5

DOI: https://doi.org/10.35619/iiu.v0i9.124

Сяська Інна

кандидат педагогічних наук, доцент, докторант кафедри теорії і методики виховання

Рівненського державного гуманітарного університету,

м. Рівне, Україна

ORCID: 0000-0002-6096-1335

e-mail: syaskainna@gmail.com

\title{
КОМПЕТЕНТНІСНИЙ ПІДХІД В ЕКОЛОГІЧНІЙ ПІДГОТОВЦІ МАЙБУТНІХ УЧИТЕЛІВ ПРИРОДНИЧИХ ДИСЦИПЛІН: ТЕОРЕТИКО-МЕТОДОЛОГІЧНИЙ АСПЕКТ
}

\begin{abstract}
Анотація. У статті проаналізовано проблеми формування екологічної компетентності особистості як кінцевої мети і результату екологічної освіти. Запропоновано власне визначення поняття «екологічна компетентність учителя природничих дисциплін», яке трактуємо як здатність застосовувати систему знань, умінь та досвід екологічної діяльності у професійних і життєвих ситуаціях, розуміти й пояснювати стратегію сталого розвитку суспільства й природи; володіти практичним досвідом екологічно доцільної діяльності у довкіллі, бажанням брати особисту участь та виховувати в учнів прагнення до відновлення й збереження природного середовища; на основі пріоритетності екологічних цінностей та особистісних якостей (екологічна свідомість й самосвідомість, екологічна відповідальність й активність) формувати екологічну культуру й світогляд школярів, виявляти готовність до природоохоронної й еколого-натуралістичної роботи 3 учнями. Наголошується на необхідності включення екологічної компетентності до переліку базових, загальних та фахових компетентностей випускника вищого закладу освіти. Обгрунтовано методологічні основи впровадження компетентнісного підходу в процес екологічної освіти студентів природничих факультетів вищих педагогічних закладів освіти, які базуються на: онтологічних, гносеологічних, аксіологічних і пракселогічних положеннях та підходах.

Ключові слова: компетентнісний підхід, компетенція, компетентність, екологічна компетентність учителя природничих дисциплін, екологічна освіта, заклад вищої освіти.
\end{abstract}

Постановка проблеми. Впровадження компетентнісного підходу в екологічну освіту у вищій педагогічній школі на сьогодні $є$ надзвичайно актуальним i затребуваним, оскільки дає змогу розкрити сучасні світові тенденції розвитку освіти з одного боку, а з іншого, модернізувати екологічну підготовку майбутніх учителів відповідно до нових соціально-екологічних процесів у світі та трансформації суспільних екологічних поглядів та ставлень. I якщо перше завдання передбачає побудову організаційно-змістової структури екологічної освіти, то інше - осмислення іiі загального концептуального підгрунтя, ідеології, й аксіологічних основ. На нашу думку, зазначені детермінанти визначають основоположні проблеми i завдання розвитку екологічної освіти у закладах вищої педагогічної освіти й зумовлюють перспективи подальших досліджень у цій галузі. 
У ракурсі досліджуваної проблематики компетентнісний підхід передбачає формування не лише базових (ключових) компетентностей, а й екологічної компетентності майбутнього педагога. Тож, зміст екологічної освіти, на думку М. П. Горшеніної, М. Д. Варламової (2014, с. 134), переформатовується зі знаннєвої концепції на концепцію накопичення досвіду застосування здобутих екологічних знань, умінь і навичок у різноманітних професійних і життєвих ситуаціях.

Аналіз основних досліджень $з$ проблеми. Загальні підходи в організації компетентнісно-орієнтованої вітчизняної професійної педагогічної освіти висвітлювалися у працях Н. М. Бібік, Л. С. Ващенка, О. А. Дубасенюк О. І. Локшиної, Н. Г. Ничкало, О.В.Овчарук, Л. І. Паращенко, О. І. Пометун, О. Я. Савченко, О.В.Шестопалюка, В.В.Ягупова та ін. Проте на сьогодні немає єдиної концепції впровадження компетентнісного підходу у підготовці майбутніх учителів, оскільки державний стандарт вищої освіти для спеціальності 014 «Середня освіта» не затверджений і перебуває на стадії розроблення.

Науковці зарубіжної і вітчизняної педагогіки сходяться на думці, що реалії екологічної кризи сучасності зумовлюють набуття особливого статусу екологічної освіти, яка стає обов'язковим компонентом навчально-виховного процесу усіх рівнів освіти, а кінцевим іï результатом $\epsilon$ екологічна компетентність особистості. Зокрема, С. В. Шмалей $(2005$, с.4) зазначає, що екологічна компетентність - це головна мета і результат екологічної освіти, інтегральний особистісний розвиток, що забезпечує здатність виокремлювати, розуміти, оцінювати сучасні екологічні процеси, спрямовані на забезпечення екологічної рівноваги та раціонального природокористування.

Проблеми формування екологічної компетентності особистості розроблялися О. В. Гуренковою, С. А. Ждановою, О. О. Колоньковою, Н. В. Куриленко, Я. О. Логвіновою, Л. Б. Лук'яновою, О. Л. Пруцаковою, Н. А. Пустовіт, Л. Д. Руденко, Л. М. Титаренко А. Л. Хрипуновою, Н. О. Черновол, С. В. Шмалєй та ін. Однак дослідження цієї проблемної галузі проводилися здебільшого або на рівні загальної середньої, або вищої професійної освіти переважно технічного й інженерного профілів. Тоді як реалізація компетентнісного підходу у вищій педагогічній освіті у контексті формування екологічної компетентності майбутніх учителів природничих дисциплін розроблена фрагментарно і потребує теоретико-методологічного обгрунтування.

Мета статті: обгрунтувати теоретичні та методологічні засади застосування компетентнісного підходу в екологічній освіті студентів природничих факультетів вищих педагогічних закладів освіти.

Виклад основного матеріалу дослідження. Впровадження компетентнісного підходу в освіту має глибокі історичні передумови на фоні формування постіндустріального суспільства, що супроводжувалося наростанням соціально-цивілізаційної кризи, зокрема й екологічної. Тому особливо важливого значення набуває неперервна екологічна освіта, що зорієнтована на збереження i відтворення природних багатств на засадах збалансованого природокористування та забезпечення сталого розвитку природи і суспільства.

Значущою складовою цієї освіти є професійна підготовка екологічно компетентного учителя, здатного реалізувати адекватну екологічну освіту i 
виховання учнівської молоді відповідно до вимог сьогодення. 3 цього приводу актуальною є думка Л. Б. Лук'янової (2005, с. 54): «...екологічна освіта - це не частина освіти, а новий сенс і мета сучасного освітнього процесу - унікального засобу збереження й розвитку людини і продовження людської цивілізації, це процес, який перебуває у постійному розвитку і $є$ результатом переорієнтації та узгодження різних дисциплін». Такий підхід щодо розуміння ролі і місця екологічної освіти в освітньому процесі дає підстави для висновку, що екологічна компетентність особистості займає особливе місце у системі компетентностей майбутнього фахівця.

По-перше, екологічна компетентність на глобальному соціокультурному рівні виступає необхідним компонентом ключових (надпредметних) компетентностей особистості, $є$ основою для розвитку екологічної культури i свідомості. По-друге, екологічна компетентність входить до складу загальних (загальногалузевих) компетентностей, iї формування передбачає здатність випускника будь-якого закладу освіти розуміти стратегію сталого розвитку суспільства й природи та втілювати іiі на практиці як у побуті, так і в професійній діяльності. I по-третє, екологічна компетентність також $\epsilon$ складовою спеціальних (фахових) компетентностей, що реалізується у змісті екологічних дисциплін та формується у результаті застосування здобутих у процесі навчання екологічних знань і вмінь у професійній діяльності в галузі екології і збалансованого природокористування.

У цьому контексті, на нашу думку екологічна компетентність передбачає оволодіння науковими знаннями про взаємозв'язки у системі «природа людина - суспільство»; розуміння сучасних проблем навколишнього середовища, усвідомлення відповідальності про стан довкілля на глобальному, регіональному та локальному рівнях; вміння приймати відповідальні рішення щодо екологічних проблем, оволодіння нормами екологічно доцільної поведінки і діяльності у довкіллі та розвиток ціннісно-мотиваційної сфери особистості у ставленні до природи (Сяська, 2018, с. 255).

Як зазначалося вище, формування екологічної компетентності є одним із головних завдань неперервної екологічної освіти. Однак О. Л. Пруцакова (2009, с.132) 3 цього приводу справедливо відмітила: «у переліку ключових компетентностей, як i в структурі поняття «життєва компетентність», екологічний компонент практично не представлений». За визначенням авторів монографії «Компетентнісний підхід до підготовки педагогів у зарубіжних країнах: теорія та практика» (Авшенюк та ін., 2014, с.9) ключові (надпредметні) компетентності покликані реалізувати здатність людини здійснювати складні поліфункціональні, поліпредметні, культуродоцільні види діяльності, ефективно розв'язуючи відповідні проблеми. У контексті глобальної екологічної кризи та наростання масштабних екологічних проблем у нашій державі екологічна компетентність має розглядатися як важлива складова ключових компетентностей особистості, іiі соціальної адаптації до екологічних умов життя в сучасному світі. Відповідно, потребує негайної уваги методологічна й теоретична розробка цього питання.

Методологічні основи впровадження компетентнісного підходу в процес екологічної освіти студентів природничих факультетів вищих педагогічних закладів освіти базуються на:

- онтологічних філософсько-культурологічних положеннях про діалектичне пізнання явищ і процесів взаємозалежності та взаємодії природи і 
людини, в яких обгрунтовуються ідеї коеволюції, сталого розвитку природи i суспільства та необхідність гармонізації взаємовпливів у системі «природа людина - суспільство»;

- гносеологічній концепції, яка характеризує основні етапи процесу засвоєння знань (відчуття, сприйняття, осмислення, розуміння, узагальнення, закріплення, застосування) та відображає взаємозв'язок знаннєвої, ціннісної та мотиваційно-діяльнісної складової як базису поведінки і діяльності особистості у навколишньому природному середовищі;

- аксіологічному визнанні суб'єктного ставлення до природи та непрагматичного характеру взаємодії з нею, що засноване на пріоритетності екологічних ціннісних орієнтацій;

- праксеологічних засадах ефективної екологічно доцільної діяльності у довкіллі, займання активної екологічної позиції в процесі вирішення професійних і життєвих ситуацій на основі сформованої системи екологічних цінностей у ставленні до природи.

Теоретичне обгрунтування застосування компетентнісного підходу в екологічній освіті майбутніх учителів природничих дисциплін потребує чіткого розмежування його основоположних понять. Так, у сучасній вітчизняній і зарубіжній педагогіці склалися неоднозначні й часто суперечливі визначення змісту компетентнісного підходу, сутності й ієрархії понять «компетенція» та «компетентність» (Ягупов та Свистун, 2007, с.4).

Узагальнивши наукові дослідження 3 цієї проблематики, пропонуємо системний підхід до трактування іiі базових понять. Під компетентнісним підходом у вищій освіті розуміємо переорієнтацію освітньої парадигми 3 метою підготовки майбутніх фахівців, здатних оперативно і творчо приймати рішення у професійній діяльності, опираючись на досвід застосування здобутих знань, умінь і навичок у процесі навчання в закладі вищої освіти. Інтегрованим результатом застосування компетентнісного підходу у навчально-виховному процесі слід вважати сформованість системи компетенцій - наперед заданих соціальних вимог та норм до рівня професійної підготовки випускника вищого закладу освіти. Тоді компетентність розглядаємо як ступінь оволодіння майбутнім фахівцем заданою компетенцією, що забезпечується сформованими особистісними якостями студента: ставленнями, цінностями й переконаннями.

Процес формування компетентності, на нашу думку, $\epsilon$ поетапним i передбачає перехід здобувача освіти на послідовні ступені оволодіння заданою компетенцією (Сяська, 2018, с.182). Першим ступенем цього процесу вважаємо набуття грамотності, яку в цьому контексті ми трактуємо як мінімальне засвоєння знань, умінь і навичок, необхідних для здобуття всебічної освіти. Зазвичай зазначений процес завершується здобуттям базової середньої освіти у загальноосвітньому навчальному закладі. Другий ступінь - формування освіченості - починається 3 навчання учня у старшій профільній школі, продовжується у закладах професійної освіти та передбачає набуття здатності креативно застосовувати здобуті знання, уміння і навички у повсякденній діяльності, що безпосередньо залежить від особливостей ціннісно-емоційного сприйняття особистості оточуючої дійсності. Завершальний ступінь формування компетентності - відображає рівень оволодіння знаннями, уміннями і навичками у професійній діяльності, що узагальнюється набуттям 
досвіду оптимального вирішення проблем прикладного характеру на основі власних моральних цінностей, прерогатив і переконань.

У процесі формування екологічної компетентності особистості важливим моментом $\epsilon$ предметна область майбутньої професійної діяльності, яка так чи інакше відкладає відбиток на практичний досвід актуалізації накопичених екологічних знань й ціннісно детермінованих переконань. Таким чином, екологічну компетентність учителя природничих дисциплін трактуємо як здатність застосовувати систему знань, умінь та досвід екологічної діяльності у професійних і життєвих ситуаціях, розуміти й пояснювати стратегію сталого розвитку суспільства й природи; володіти практичним досвідом екологічно доцільної діяльності у довкіллі, бажанням брати особисту участь та виховувати в учнів прагнення до відновлення й збереження природного середовища; на основі пріоритетності екологічних цінностей та особистісних якостей (екологічна свідомість й самосвідомість, екологічна відповідальність й активність) формувати екологічну культуру й світогляд школярів, виявляти готовність до природоохоронної й еколого-натуралістичної роботи з учнями.

У підготовці майбутнього учителя центральне місце посідає освітньопрофесійна програма, зміст якої регламентується стандартом вищої освіти i безпосередньо реалізує очікувані результати навчання i формування компетентностей у тому числі екологічної. 3 метою забезпечення формування екологічної компетентності майбутніх учителів природничих дисциплін (фізики, хімії, географії, біології, природознавства, екології) у проекти стандартів вищої освіти спеціальності 014 «Середня освіта» зазначених предметних спеціалізацій, на наш погляд, необхідно внести наступні зміни:

- включити екологічну компетентність у перелік загальних компетентностей для забезпечення освіти в інтересах сталого розвитку. Слід відмітити, що реалізацію цього завдання вбачаємо у екологізації загальноосвітніх дисциплін, залучення студентів до діяльності природоохоронного волонтерського руху, активізації роботи студентського самоврядування у проведенні екологічних заходів та акцій;

- актуалізувати екологічну складову у змісті фахових природничих дисциплін за рахунок міждисциплінарного характеру екологічних знань;

- забезпечити накопичення практичного досвіду втілення ціннісних екологічних орієнтацій, знань i вмінь завдяки проходженню студентами різнопланових навчально-польових (екологічних стежин, експедицій, походів, екскурсій) та виробничих педагогічних практик, виконання лабораторних $\mathrm{i}$ практичних робіт, курсових та дипломних проектів екологічного спрямування.

Висновки та перспективи подальших розвідок. Отже, теоретикометодологічне обгрунтування застосування компетентнісного підходу в екологічній освіті студентів природничих факультетів вищих педагогічних закладів освіти дасть змогу визначити оптимальні підходи для створення навчально-методичного супроводу та відповідного освітнього середовища для ефективного формування екологічної компетентності майбутніх педагогів. Проведене дослідження не вичерпує коло питань, які необхідно вирішити для якісної підготовки фахівця в галузі природничої педагогічної освіти, здатного застосовувати здобуті екологічні знання й досвід для вирішення професійних задач і у життєвих ситуаціях, та здійснювати адекватну екологічну освіту i виховання підростаючого покоління. 


\section{СПИСОК ВИКОРИСТАНИХ ДЖЕРЕЛ:}

Горшенина, М., Харламова, М. (2014). К вопросу о компетентностном подходе экологическом образовании. Вестник Российского университета дружбы народов, серия: «Экология и безопасность жизнедеятельности», 1, сс. 132-137.

Шмалєй, С. (2005) Система екологічної освіти в загальноосвітній школі в прочесі вивчення предметів природничо-наукового ииклу: автореферат дис. ... докт. пед. наук. Український державний пед. ун-т ім. М.П. Драгоманова. 44 с.

Лук'янова, Л. (2006). Теорія $i$ практика екологічної освіти у професійнотехнічних навчальних закладах. Доктор педагогічних наук. Інститут педагогіки i психології професійної освіти АПН України. 465 с.

Сяська, І. Сутність екологічної компетентності та особливості її формування у майбутнього учителя природничих дисциплін. Інноватика у вихованні, Вип. 8, cc.251-259.

Пруцакова, О. (2009). До проблеми формування екологічної компетентності школярів. Вісник Черкаського університету. Серія: Педагогічні науки, Вип. 162, сс. 132-138.

Авшенюк, Н., Десятов, Т., Дяченко, Л., Постригач, Н., Пуховська, Л. та Сулима, О. (2014). Компетентнісний підхід до підготовки педагогів у зарубіжних краӥнах: теорія та практика: монографія. Кіровоград: Імекс-ЛТД. 280 с.

Ягупов, В. та Свистун, В. (2007). Компетентнісний підхід до підготовки фахівців у системі вищої освіти. Наукові записки. Педагогічні, психологічні науки mа соиіальна робота, Том 71. Режим доступу : http://ekmair.ukma.edu.ua/handle /123456789/6871 [Дата звернення 26 березня 2019].

Сяська, I. (2018). До проблеми впровадження компетентнісного підходу у процес фахової підготовки майбутніх учителів природничих дисциплін. Педагогічні науки: теорія, історія, інноваційні технологї, № 10 (84), сс. 179-189.

\section{REFERENCES:}

Gorshenina, M., Kharlamova, M. (2014). K voprosu o kompetentnostnom podkhode ekologicheskom obrazovanii [On the Issue of Competence-based Approach to Ecological Education]. Vestnik Rossiiskogo universiteta druzhby narodov, seriya: "Yekologiya i bezopasnost zhyznedeyatelnosty», No1, ss. 132-137. [in Russian]

Shmaliei, S. (2005). Systema ekolohichnoi osvity v zahalnoosvitnii shkoli v protsesi vyvchennia predmetiv pryrodnycho-naukovoho tsyklu: avtoreferat [The System of Ecological Education in Secondary School in the Process of Studying the Subjects of the Natural Sciences Cycle: the author's abstract]. Ukrainskyi derzhavnyi ped. un-t im. M. P. Drahomanova. 44 s. [in Ukrainian]

Lukianova, L. (2006). Teoriia $i$ praktyka ekolohichnoi osvity u profesiinotekhnichnykh navchalnykh zakladakh [The Theory and Practice of Environmental Education in Vocational Schools]. Doktor pedahohichnykh nauk. Instytut pedahohiky i psykholohii profesiinoi osvity APN Ukrainy. $465 \mathrm{~s}$. [in Ukrainian]

Siaska, I. Sutnist ekolohichnoi kompetentnosti ta osoblyvosti ii formuvannia u maibutnoho uchytelia pryrodnychykh dystsyplin [The Essence of Ecological Competency and the Peculiarities of its Formation in the Future Teacher of Natural Disciplines]. Innovatyka u vykhovanni, Vyp. 8, ss.251-259. [in Ukrainian]

Prutsakova, O. (2009). Do problemy formuvannia ekolohichnoi kompetentnosti shkoliariv [On the Issue of the Problem of Formation the Ecological Competency in Schoolchildren]. Visnyk Cherkaskoho universytetu. Ceriia: Pedahohichni nauky, Vyp. 162, ss. 132-138. [in Ukrainian]

Avsheniuk, N., Desiatov, T., Diachenko, L., Postryhach, N., Pukhovska, L. ta Sulyma, O. (2014). Kompetentnisnyi pidkhid do pidhotovky pedahohiv u zarubizhnykh krainakh: teoriia ta praktyka: monohrafiia [Competence Approach to Ttraining Teachers 
in Foreign Countries: Theory and Practice: Monograph]. Kirovohrad: Imeks-LTD. 280 s. [in Ukrainian]

Yahupov, V. ta Svystun, V. (2007). Kompetentnisnyi pidkhid do pidhotovky fakhivtsiv u systemi vyshchoi osvity [Competence Approach to Training in the System of Higher Education]. Naukovi zapysky. Pedahohichni, psykholohichni nauky ta sotsialna robota, Tom 71. Rezhym dostupu : http://ekmair.ukma.edu.ua/handle /123456789/6871 [Data zvernennia 26 bereznia 2019]. [in Ukrainian]

Siaska, I. (2018). Do problemy vprovadzhennia kompetentnisnoho pidkhodu u protses fakhovoi pidhotovky maibutnikh uchyteliv pryrodnychykh dystsyplin [On the Issue of Implementation of a Competent Approach in the Process of Professional Training of Future Teachers of Natural Disciplines]. Pedahohichni nauky: teoriia, istoriia, innovatsiini tekhnolohii, No 10 (84), ss. 179-189. [in Ukrainian].

\title{
COMPETENTCE APPROACH TO ECOLOGICAL TRAINING OF FUTURE TEACHERS OF NATURAL DISCIPLINES: THEORETICAL- METHODOLOGICAL ASPECT
}

\author{
Inna Siaska \\ PhD., Associate Professor, Doctoral student \\ at the Department of Theory and Methods of Education \\ Rivne State University of the Humanities, \\ Rivne, Ukraine \\ ORCID: 0000-0002-6096-1335 \\ e-mail: syaskainna@gmail.com
}

\begin{abstract}
The article deals with the problems of the formation of ecological competency of the individual as the ultimate goal and the result of ecological education. It was established that the formation of competency takes place in stages. The successive degrees of mastering the given competence are determined: literacy, education, competency. It is emphasized the need to include ecological competency in the list of basic, general and professional competencies of a graduate of a higher educational establishment. The actual definition of the concept "ecological competence of the teacher of natural disciplines" is proposed, which is interpreted as the ability to apply a system of knowledge, skills and experience of environmental activities in professional situations and everyday life, to understand and explain the strategy of sustainable development of society and nature; to master with expedient activity in the environment, the desire to take personal participation and to bring up students in the desire to restore and keep the natural environment; on the basis of the priority of environmental values and personal qualities (ecological consciousness and self-awareness, environmental responsibility and activity) to form the ecological culture and outlook of schoolchildren, to show readiness for nature protection and ecological-naturalistic work with children. The methodological bases of implementation of the competence approach in the process of ecological education of students at natural sciences faculties of higher educational institutions of education: ontological, epistemological, axiological and praxiological principles and approaches, are substantiated. In the context of formation of the ecological competency of the future teacher of natural disciplines, it is proposed to make changes to the projects of higher education standards of the specialty 014 "Secondary education" of natural specialization.

Key words: competence approach, competence, competency, ecological competence of a teacher of natural disciplines, ecological education, institution of higher education.
\end{abstract}

Стаття надійшла до редакиії 12.04.2019 p. 